\title{
ЭФФЕКТИВНОЕ СОТРУДНИЧЕСТВО КЛАССНОГО РУКОВОДИТЕЛЯ С РОДИТЕЛЯМИ РАДИ ОБЩИХ ЦЕЛЕЙ, ИНТЕРЕСОВ И ЗАДАЧ
}

\author{
Кольцова Валентина Васильевна \\ МАОУ гимназия №120, г. Екатеринбург
}

Аннотация: Статья посвящена системе работы с родителями в школе. В статье рассматриваются эффективные формы работы с родителями учащихся, методы работы классных руководителей, помогающие во взаимодействии с родителями учеников.

Ключевые слова: Сотрудничество, воспитание, родители, семья, родительские собрания, родительский комитет.

Преобразования, происходящее в нашей стране (экономические, политические и социальные) в последнее время резко обострили социальные противоречия. Ослабление брачных уз, снижение рождаемости и другие явления, способствовали снижению качества и содержания семейного воспитания, усилилась напряженность во взаимоотношениях семьи и школы.

Формирование эффективных сотруднических отношений школы и семьи - это результат длительной, целенаправленной работы, которая прежде всего, зависит от того, как складывается взаимодействие взрослых в этом процессе. А результат воспитания может быть успешным только тогда, когда учителя и родители имеют общие цели, интересы и задачи, становятся сотрудниками. Сотрудничество учителя и родителей существует не самого себя ради, а ради общих целей, интересов и задач.

Ведущую роль в организации сотрудничества школы и семьи играют классные руководители. Именно от их работы зависит то, насколько семьи понимают догму, образовательного учреждения по отношении воспитания, обучения детей, и участвуют в ее реализации. При этом семья должна рассматриваться как главный союзник в воспитании детей.

В основе сотруднического взаимодействия семьи и классного руководителя должны лежать принципы взаимного доверия и уважения, поддержки и помощи, терпения и терпимости по отношению друг к другу. 
Педагоги, занимаясь с учениками, порой забывают про родителей. Важна не «адаптация» родителей, о степень их участия в жизни класса и школы.

Работа с родителями - это одна из самых трудных, хлопотных и неблагодарных составляющих работы классного руководителя. Однако не все родители осознают это.

Во многих семьях бывает так, что один ребёнок хороший, а второй ещё лучше. А классным руководителем становишься не только для учеников, но и для их семей с мамами, папами, бабушками, дедушками, и т.д. и т.п. Все они со своими характерами, взглядами, убеждениями, семейными устоями, традициями, проблемами и претензиями.

От того, насколько совпадут чаяния родителей со стремлениями классного руководителя, насколько удастся педагогу убедить, привлечь на свою сторону родителей, от тех связей и взаимоотношений, которые возникнут в начальный период знакомства, будет во многом зависеть и вся последующая работа. Это не всегда удаётся на 100\%. Чтобы осуществлялось сотрудничество, необходимо учителю и родителям стать единомышленниками и союзниками. Все начинается с первой встречи с родителями.

Первое собрание.

Для формирования сотрудничества важно представлять классный коллектив как единое целое, как большую семью, которая сплачивается и интересно живёт. Для этого должна организовываться совместная деятельность. Продумываются предстоящие походы, поездки, выходы на природу, музеи, концерты, театры и т.д. Это помогает сплотить как детей, так и родителей.

\section{Подготовка кабинета.}

Парты стоят по периметру класса (по кругу). Для каждого родителя заранее приготовлена карточка с собственным именем мамы и на обратной стороне папы. В зависимости от присутствия используется та или другая сторона. Родители должны видеть друг друга и педагога, а не затылок впереди сидящего. Нужно будет решать общие проблемы, объединяться в коллектив, союз. В основе этого союза - единство стремлений, взглядов, совместно выработанных целей, нахождение путей реализации планов. 
С первой встречи родители должны видеть в учителе человека авторитетного, знающего и способного найти решения в любой, самой сложной ситуации.

Выборы родительского комитета.

Одной из форм участия родителей в жизни класса является деятельность родительского комитета. $\mathrm{B}$ родительский комитет входят самые инициативные интересующиеся общественными делами родители, которые выбираются общим голосованием. В поле зрения родительского комитета входят вопросы организации родительских собраний, установление контактов с другими родителями, организации в классе мероприятий учебного и внеучебного плана. Заседание родительского комитета проходит обычно 2 раза в четверть или по мере необходимости. Перед родительским собранием и после него формируются вопросы по повестке очередного родительского собрания, распределяются обязанности, назначаются ответственные, курирующие или контролирующие выполнение намеченных задач. Таким образом, готовится повестка, предлагаются для обсуждения актуальные вопросы, подготовленные варианты решений. Поэтому собрания проходят интересно, нет «балагана», недопонимания при обсуждении проблем.

Контакты с семьями обучающихся.

Работая с родителями, важно достичь обоюдного откровения и понимания. Без сомнения, многие классные руководители поддерживают открытые и тесные связи с семьями, т.к. понимают, что обучение - это совместная работа учителей и родителей. Хотя немало педагогов, старающихся сохранить дистанцию при общении с родителями.

Взаимоотношения учителей, родителей и учеников можно сравнить с равносторонним треугольником. И если стороны треугольника равны, то это прочнейшая фигура, а несовпадения и разногласия приводят к ухудшению взаимодействия и взаимопонимания всех «сторон». Поэтому, если учитель обвиняет родителей, следовательно, он сам допускает ошибки и наоборот. Без взаимодействия семьи и школы жизнь класса, как и отдельного ученика, становится беднее.

В работе классного руководителя следует придерживаться такого правила: вызывать родителей в школу только тогда, когда без их вмешательства невозможно решить проблему. А таких ситуаций бывает не так много. Конечно, звонить родителям и ставить их в известность о «шалостях» их чада нужно, иногда просто необходимо, но вызов в школу должен быть 
«высшей мерой наказания», иначе скоро это станет для них обыденностью и потеряет тот воспитательный эффект, на который мы всегда так надеемся.

Подготовка классного руководителя к приёму будущих пятиклассников.

Идеальная ситуация, когда вы заранее узнали, что в следующем учебном году вам планируется пятый класс. Здесь намного проще обеспечить преемственность требований и работу с родителями. Как это можно сделать? Выступления на родительском собрании и представление вас в качестве будущего классного руководителя учителем начальных классов, знакомство родителей с вашими требованиями и пожеланиями, изучение личных дел учеников. Но если о своём назначении классным руководителем в пятый класс вы узнали лишь в конце августа, то свою работу нужно строить иначе.

Для того, чтобы увлечь детей, мотивировать их и родителей к совместной деятельности, каждый учебный год нужно начинать ярко! Поэтому первый классный час обязательно должен быть необычным и запоминающимся, на него нужно пригласить всех родителей. Хорошо, если придут родители и дети предыдущих выпусков. Замечено, что на линейку первого сентября приходят практически все родители пятиклассников. Подобное общее дело поможет ближе познакомиться с ребятами и родителями. После такого классного часа рекомендуется провести первое родительское собрание в новом для родителей статусе - «родителей пятиклассника».

Кстати, о приглашениях и поздравлениях...

Никогда не скупитесь на внимательное отношение к родителям! На первое родительское собрание обязательно должно быть приготовлено индивидуальное приглашение. Например, на первое собрание - первого сентября можно сделать приглашение-поздравление:

Уважаемые родители!

Поздравляю Вас с началом учебного года!

Ваш сын или дочь стали пятиклассниками! Какие трудности встретятся на их пути, как с ними справиться? На эти и другие вопросы поможет ответить наша первая встреча. Организационное собрание состоится восьмого сентября в 18.30, кабинет №105. Я надеюсь, что ваше присутствие на собрании станет традицией нашего класса. С надеждой на встречу и сотрудничество.

Ваш классный руководитель Валентина Васильевна Кольцова.

В сотрудничестве нет мелочей! 
Несколько советов, которые помогут не утратить доброго расположения родителей и связи с ними. Конечно, стопроцентного участия всех родителей не добиться, однако планомерная систематическая работа принесёт свои плоды.

Полезная информация - это то, что мы чаще всего называем «педагогическим просвещением родителей», и поэтому оно должно обязательно быть на каждом родительском собрании.

Понимание и профилактика возможных проблем подкупает родителей. Взаимодействие с психологами школы, приглашение опытных специалистов повышает доверие родителей к классному руководителю, который своевременно предупреждает ту или иную (возможно, конфликтную) ситуацию.

Больше общайтесь с родителями. Как часто мы это делаем? Когда нужно сообщить о каком-то проступке? Рассказывайте о достижениях ребёнка, о его маленьких победах, родители обязательно ответят вам взаимной заинтересованностью.

Обязательно благодарите родителей! Это могут быть элементарные слова благодарности по итогам четверти или прошедшего мероприятия.

Только доброжелательный стиль общения, искренность, заинтересованность, желание помочь их детям и им самим дадут тот результат, о котором мечтает каждый классный руководитель. Полюбить всех без исключения учеников и родителей мы не сможем - да никто и не заставляет это делать. Но уважать их и делать свое дело - профессионально это обязанность педагога. И тогда можно услышать те слова, ради которых стоит работать: «Наш классный руководитель самый лучший!»

Школа даёт ребёнку научные знания и воспитывает у него сознательное отношение к действительности. Семья обеспечивает практический жизненный опыт, воспитывает умение сопереживать другому человеку, чувствовать его состояние. Для гармонического развития личности необходимо и то, и другое.

Общение с родителями своих учеников необходимо, так как без этого классный руководитель может оказаться лишённым важной информации. Пользуясь достаточно «продвинутыми» средствами информационных услуг, можно и родителей информировать в режиме «быстрого» взаимодействия.

Никого не удивишь возможностями эл. почты, WhatsApp, Vaiber, ZOOM. 
Ежедневно можно посылать любую необходимую информацию. Будь то д/3, объявления, уведомления, сообщения, срочная рассылка.

Не исключён телефон, но важно следовать правилам:

- знать имена и отчества родителей;

- поздравлять родителей с днём рождения их сына или дочери;

- поддержать ребёнка, выступающего на соревнованиях, олимпиадах, конкурсах, спортивных состязаниях.

- информировать родителей если ребёнок заболел, плохо ел и т.д....

Не является исключением и звонок ребятам, у которых день рождения в выходные, во время каникул; во время соревнования - пожелать успеха и «подержать кулачки».

Если есть возможность, можно посетить выступления ребят на соревнованиях, концертах, тренировках. Самое интересное, что они потом, об этом говорят. Привозят сувениры, присылают видеоотчёты, которые смотрим всем классом, и все это транслируется родителям перед собранием. Совместные поездки, экскурсии сближают детей и родителей, укрепляют дружбу и взаимопонимание в коллективе. Это очень важно, такой подход даёт правильно понять нравственные ценности и микроклимат семьи, истинны ли они, реализуются или просто декларируются.

\section{Решение сложных проблем.}

Причин здесь несколько. Это и увеличившаяся самостоятельность их ребёнка (часто детям неудобно, что их мама все ходит в школу, как будто они ещё маленькие, и они сами этому препятствуют). Есть родители которые считают: «Моей дочери/сыну уже тринадцатый год, взрослая(ый) совсем. Что же я до сих пор должна ходить и за неё(него) краснеть?»

Сюда же относятся проблемы адаптационного периода, с которым сталкиваются не только дети, но и их родители (способность найти общий язык с каждым учителем-предметником иногда не под силу некоторым родителям).

Ещё одна причина - это возникновение новых, неожиданных для многих родителей, трудностей с учёбой и поведением, о которых они сначала внимательно слушают, а затем, махнув рукой, в силу своей занятости, пускают все на самотёк (например, проблемы подросткового возраста, когда иной раз родители не могут найти общий язык со своим ребёнком).

Да и сами учителя часто делают ошибки, о которых написано в любой книге по классному руководству - начинают разговор с родителями с жалоб и 
проблем, «выливают» на них весь негатив и ждут при этом понимания. Но при подобном «нападении на их чад» можно получить в ответ: «Мой ребёнок самый лучший, вы у себя в школе порядок наведите». Естественно, что в такой ситуации контакт с родителями будет потерян, и понадобится приложить много усилий, чтобы наладить сотрудничество с этой семьёй.

Нельзя забывать, что родители смотрят на школу глазами детей. Если ребёнку хорошо, комфортно и радостно, родители спокойны. Поэтому установить контакт с детьми, детей друг с другом, а затем учителя с родителями - приоритетные задачи классного руководителя.

Обычно родители делятся на две группы:

Те, которые знают, что их ребёнок в школе оценивается положительно, они ждут похвалы.

Те, которые знают о трудностях детей, но боятся об этом говорить, избегают учителя, и не знают, как помочь ребёнку. Такие родители предпочитают вообще не ходить в школу, ограничиться лишь телефонными звонками, или приходить в школу лишь по приглашению учителя. Часто их пугают и возможные упрёки со стороны других родителей. На эту группу родителей классный руководитель должен обратить особое внимание.

Анализируя обращения родителей, которые приходят на родительские собрания, беспокоят:

- проблемы поведения и общения со взрослыми и сверстниками;

- конфликты детей;

- возможное недовольство дружбой детей.

Такие тревоги на всеобщее обсуждение выносить никогда нельзя. Здесь работа тонкая и индивидуальная.

Работая с классами, классному руководителю необходимо привлекая родителей к участию в жизни класса, обращать самое серьёзное внимание на поошрение родителей. Эта традиция должна сохраняться в течение всего периода обучения.

Организация подготовки и участия семьи в проектной деятельности ребёнка.

- Современный мир очень динамичен, и меняется он стремительно. С началом XXI века становится все более очевидным, что умения и навыки исследовательского поиска в обязательном порядке требуются не только тем, чья жизнь уже связана или будет связана с научной работой, они необходимы каждому человеку. 
- Профильное обучение, индивидуальный отбор, исследовательские проекты, олимпиады, научно - практические конференции. Конечно же, это тема отдельного разговора, но работа проводится, и в ней невозможно обойтись без участия родителей, без разнообразного сотрудничества на различных уровнях: начиная с помощи в выборе темы первого проекта и заканчивая подготовкой к её защите, оформлению и подачей материала. В 7 классе ребята представят на «суд» товарищей и родителей свои работы. Темы самые разнообразные, различного уровня сложности и самостоятельности. Приобретённый опыт (в том числе и защиты своих изысканий), будет большим подспорьем ребятам в дальнейшей учёбе и жизни.

Публичная защита первых массовых проектов.

Вот моменты, когда родителям нужно показывать достижения своего ребёнка. Оценивая окружающих, дать оценку своему ребёнку бывает очень сложно. Но когда родитель видит плоды работы - говорить ничего не надо. Такая форма работы формирует правильное понимание требований при изучении профильных дисциплин.

Поэтому взаимодействие с родителями происходит лучше, если она основывается на формах работы, тесно связанных со школой.

Работа классного руководителя с родителями очень сложная. Для успешной работы классный руководитель должен обладать педагогическим мастерством, подразумевающим знания и любовь к своей работе.

Подводя итог всему сказанному, важно отметить актуальность темы сотрудничества с родительской общественностью и пожелать учителям успешной работы, достойной этой работы зарплаты и морального удовлетворения.

Пусть родители учеников говорят о вас:

«Наша учительница прекрасна во всех отношениях. Я получаю всестороннюю информацию об успеваемости, поведении и общении своего ребёнка. Она хороший помощник. Никогда не скажет плохо о ребёнке у всех на виду. Её можно спросить обо всем, что интересует, и она всегда тактично ответит, посоветует. Мы очень рады, что нашего ребёнка обучает и воспитывает прекрасный учитель и человек». 